\title{
Development and validation of an internet entrepreneurial self-efficacy scale
}

\author{
Yi-Shun Wang \\ Department of Information Management, \\ National Changhua University of Education, Changhua, Taiwan \\ Timmy H. Tseng \\ Department of Business Administration, \\ Fu Jen Catholic University, New Taipei City, Taiwan \\ Yu-Min Wang \\ Department of Information Management, \\ National Chi Nan University, Puli, Taiwan, and \\ Chun-Wei Chu \\ Department of Information Management, \\ National Changhua University of Education, Changhua, Taiwan
}

\begin{abstract}
Purpose - Understanding people's intentions to be an internet entrepreneur is an important issue for educators, academics and practitioners. The purpose of this paper is to develop and validate a scale to measure internet entrepreneurial self-efficacy.

Design/methodology/approach - Based on an analysis of 356 responses, a scale of internet entrepreneurial self-efficacy is validated in accordance with established scale development procedures.

Findings - The internet entrepreneurial self-efficacy scale has 16 items under three factors (i.e. leadership, technology utilization and internet marketing and e-commerce). The scale demonstrated adequate convergent validity, discriminant validity and criterion-related validity. Nomological validity was established by the positive correlation between the scale and, respectively, internet entrepreneurship knowledge and entrepreneurial intention.

Originality/value - This study is a pioneering effort to develop and validate a scale to measure internet entrepreneurial self-efficacy. The results of this study are helpful to researchers in building internet entrepreneurship theories and to educators in assessing and promoting individuals' internet entrepreneurial self-efficacy and behavior.
\end{abstract}

Keywords Measurement, Scale development, Internet entrepreneurial intention, Internet entrepreneurial self-efficacy, Internet entrepreneurship

Paper type Research paper

\section{Introduction}

The increasing ubiquity of the internet has resulted in a boom in internet entrepreneurship (Engard, 2016). Entrepreneurs are turning to online businesses instead of traditional brick-and-mortar businesses because of the lower startup costs, broad reach and ability to directly interact with consumers that the internet enables (Davis, 2013; Engard, 2016).

(C) Yi-Shun Wang, Timmy H. Tseng, Yu-Min Wang and Chun-Wei Chu. Published by Emerald Publishing Limited. This article is published under the Creative Commons Attribution (CC BY 4.0) licence. Anyone may reproduce, distribute, translate and create derivative works of this article (for both commercial \& non-commercial purposes), subject to full attribution to the original publication and authors. The full terms of this licence may be seen at $\mathrm{http}: / /$ creativecommons.org/licences/by/4.0/legalcode

The research was substantially supported by the Ministry of Science and Technology of Taiwan under the Grant Number MOST 105-2511-S-018-013-MY3.

entrepreneurial self-efficacy

scale

653

Received 5 July 2018 Revised 24 February 2019

21 October 2019

Accepted 22 October 2019 
INTR

30,2

654

According to data collected by Ubot Studio, a marketing automation software company, the e-commerce industry is worth more than $\$ 200 \mathrm{bn}$ in the USA alone, a figure that is expected to grow by 15 percent each year (Davis, 2013). New internet ventures are being created every day in developed and developing economies (Guo et al., 2016). Internet entrepreneurship refers to using information technology to start a business and then conducting related business transactions solely over the internet (Wang et al., 2016). The growth of internet entrepreneurship is fueled by advancements in communications technologies, computers and smart devices (Guo et al., 2016). Uber, a ridesharing company, is a successful example of an internet startup (Guo et al., 2016). Entrepreneurs have used social media to start online businesses such as Mommy blogs, fashion and beauty blogs and craft micro-enterprises like Etsy (Duffy and Pruchniewska, 2017) as well as run businesses within the framework of the Internet-of-Things (Yu et al., 2017). Because entrepreneurial activity is closely related to economic growth (Sebora et al., 2009), many countries have invested large amounts of money and resources to encourage entrepreneurship. For instance, the US Department of Commerce (2016) recently invested $\$ 15 \mathrm{~m}$ in non-profit organizations, institutions of higher education and entrepreneurship-focused organizations across the USA. In China, policies benefiting entrepreneurship have been introduced, including streamlining administration, delegating power, providing financial support and other supportive measures (Confucius Institute, 2016). Despite the upsurge in interest related to internet entrepreneurship, most people still have low intentions to start their own businesses on the internet. This raises an interesting research question:

$R Q 1$. What factors facilitate people's online entrepreneurial intention?

Past studies of offline contexts have identified entrepreneurial self-efficacy, a person's belief or confidence in his/her ability to successfully launch an entrepreneurial venture, as an important antecedent of entrepreneurial intention (Barbosa et al., 2007; Boyd and Vozikis, 1994; McGee et al., 2009; Zhao et al., 2005). As a result, scholars developed an entrepreneurial self-efficacy scale, which has been used to differentiate entrepreneurs from managers (Chen et al., 1998) and predict entrepreneurial intention (Chen et al., 1998; Naktiyok et al., 2010; Zhao et al., 2005). The entrepreneurial self-efficacy scale has been widely used in the offline contexts, but a scale suitable for online contexts has not yet been developed.

There is a need for an online scale because internet entrepreneurship is different from traditional offline entrepreneurship in several respects. First, online entrepreneurship incorporates the internet as part of its value proposition (Devsaran, 2017). Traditional entrepreneurship does not exclude the internet. Rather, the internet is an addition rather than the primary focus for traditional businesses (Devsaran, 2017). Second, internet entrepreneurs require some technical abilities, such as website creation, basic HTML knowledge and use, internet marketing knowledge (including social media marketing, search engine optimization, how to foster a connection with target audiences, copywriting, list generation skills and ability to drive traffic to websites), which are not as crucial for the offline entrepreneur (Ryan, 2017; Smale, 2016; Strauss and Frost, 2014; WAHM, 2009). Furthermore, since customers look for convenience when they shop online and can easily search online for solutions to their problems, internet entrepreneurs must have the skills to make use of new technologies and online tools/applications to meet these needs (Wilson, 2013). Third, online businesses are not as constrained by geographic and temporal boundaries (Grant, 2018; Koçoğlu et al., 2017; Wang et al., 2016). People can easily use online retailing platforms and start their own businesses at a low-cost (Grant, 2018; Wang et al., 2016). Existing scales for entrepreneurial self-efficacy focus on leadership, traditional marketing and business operation skills (Table I). These scales fail to capture the unique qualities of internet entrepreneurship. For example, existing scales have no items that capture internet technology utilization skills, internet marketing skills and e-commerce across boundaries. 


\begin{tabular}{|c|c|c|c|c|}
\hline Sources & Leadership & Marketing & Business operation & \multirow{4}{*}{$\begin{array}{r}\text { entrepreneurial } \\
\text { self-efficacy } \\
\text { scale }\end{array}$} \\
\hline \multirow{3}{*}{$\begin{array}{l}\text { Cardon and Kirk } \\
\text { (2015), Chen } \text { et al. } \\
\text { (1998), Forbes (2005) } \\
\text { De Noble } \text { et al. (1999), } \\
\text { Hmieleski and Baron } \\
\text { (2008), Naktiyok } \text { et al. } \\
\text { (2010) }\end{array}$} & Risk-taking & Marketing, innovation & $\begin{array}{l}\text { Financial control, } \\
\text { management }\end{array}$ & \\
\hline & \multirow{2}{*}{$\begin{array}{l}\text { Defining core purpose, building } \\
\text { an innovative environment, } \\
\text { coping with unexpected } \\
\text { challenges, developing critical } \\
\text { human resources }\end{array}$} & \multirow{2}{*}{$\begin{array}{l}\text { Developing new product } \\
\text { and market opportunities }\end{array}$} & \multirow[t]{2}{*}{$\begin{array}{l}\text { Initiating investor } \\
\text { relationships }\end{array}$} & \\
\hline & & & & \\
\hline $\begin{array}{l}\text { Schmitt et al. (2018), } \\
\text { Zhao et al. (2005) }\end{array}$ & Thinking creatively & $\begin{array}{l}\text { Successfully identifying } \\
\text { new business } \\
\text { opportunities, creating } \\
\text { new products }\end{array}$ & $\begin{array}{l}\text { Commercializing an idea } \\
\text { or new development }\end{array}$ & \\
\hline Barbosa et al. (2007) & Tolerance self-efficacy & $\begin{array}{l}\text { Opportunity-identification } \\
\text { self-efficacy }\end{array}$ & $\begin{array}{l}\text { Managerial self-efficacy, } \\
\text { relationship self-efficacy }\end{array}$ & \\
\hline McGee et al. (2009) & Marshaling & Searching & $\begin{array}{l}\text { Planning, } \\
\text { implementing-people, } \\
\text { implementing-financial }\end{array}$ & $\begin{array}{r}\text { Table I. } \\
\text { The common } \\
\text { dimensions of existing }\end{array}$ \\
\hline $\begin{array}{l}\text { Cox et al. (2002), } \\
\text { Kickul et al. (2009) }\end{array}$ & Marshaling stage & Searching stage & $\begin{array}{l}\text { Planning stage, } \\
\text { implementing stage }\end{array}$ & $\begin{array}{r}\text { entrepreneurial } \\
\text { self-efficacy scales }\end{array}$ \\
\hline
\end{tabular}

A benefit of online scale designed for online contexts is to enable educators to improve peoples' intentions to start online businesses. This new scale can help institutions design effective courses to educate potential internet entrepreneurs. In addition to developing a scale to measure internet entrepreneurial self-efficacy, the following research questions are also investigated:

RQ2. What are the underlying dimensions of internet entrepreneurial self-efficacy?

RQ3. Are internet entrepreneurial self-efficacy and entrepreneurial self-efficacy conceptually different?

RQ4. Can internet entrepreneurial self-efficacy predict entrepreneurial intention?

The remainder of this paper is organized as follows. The next section reviews the relevant literature to specify the domain of internet entrepreneurial self-efficacy and develops the research hypotheses. After this, methodological issues pertaining to item generation, data collection and scale purification are provided. Finally, theoretical and practical implications are discussed together with limitations of the study and future research directions.

\section{The domain of internet entrepreneurial self-efficacy}

2.1 Self-efficacy

Self-efficacy refers to people's self-perceptions of their abilities and skills to produce a given attainment in a given domain (Bandura, 1997; Wilson et al., 2007). People are motivated by perceived self-efficacy rather than objective ability, and this perception influences affective states and behaviors (Markman et al., 2002). Efficacy beliefs influence goal setting and goal commitment, as well as the amount of effort spent in goal pursuit, goal perseverance in the face of obstacles, resilience to adversity, emotional quality of life, degree of stress and depression experienced in dealing with taxing environmental demands and accomplishments in people's lives (Bandura, 2006).

An important feature of self-efficacy is that it is task specific and domain specific (Bandura, 1997, 2006; Boyd and Vozikis, 1994; Eccles, 1994). A one-size-fits-all scale reduces 
INTR

30,2

the predictive power of the scale. Therefore, perceived self-efficacy scales have to be tailored to the particular domain of interest (Bandura, 2006). Different self-efficacy scales have been developed in various domains such as driving, teaching, problem-solving, pain management, parenting, regulating excise and regulating eating habits.

\subsection{Entrepreneurial self-efficacy}

Entrepreneurial self-efficacy refers to an individual's belief in their capability to successfully perform the roles and tasks of an entrepreneur (Boyd and Vozikis, 1994; Scherer et al., 1989), or their belief in their ability to successfully launch an entrepreneurial venture (McGee et al., 2009). Entrepreneurial self-efficacy is a key component in the intentional model of entrepreneurial decision making (Chen et al., 1998), which postulates that an individual plays an active role, rather than a passive role, regarding the decision to create and manage their own businesses. Entrepreneurial decisions are influenced by a variety of contextual (e.g. prior work experience) and individual factors (e.g. locus of control), but they are mainly determined by one's entrepreneurial self-efficacy, which is the result of a cognitive appraisal of situational and individual factors (Chen et al., 1998; Krueger and Brazeal, 1994).

A series of studies have contributed to the development of a scale of entrepreneurial self-efficacy to predict entrepreneurial intention (e.g. Kickul et al., 2008; Naktiyok et al., 2010; Wilson et al., 2007), which distinguishes entrepreneurs from non-entrepreneurs (Chen et al., 1998; De Noble et al., 1999; McGee et al., 2009). Prior studies modeled entrepreneurial self-efficacy as a domain-specific construct related to an individual's belief or confidence in different tasks associated with core entrepreneurial activities or skills (McGee et al., 2009). Past studies noted that entrepreneurial self-efficacy is a multidimensional scale (Chen et al., 1998; De Noble et al., 1999; McGee et al., 2009; Naktiyok et al., 2010) that consists of dimensions related to general management tasks, such as marketing, strategic planning and business decision making (McGee et al., 2009). Different scales have been used in the literature to measure entrepreneurial self-efficacy (Newman et al., 2019). The multi-dimensional scales developed by Chen et al. (1998) and De Noble et al. (1999) have been the most frequently used scales (Naktiyok et al., 2010). The former is composed of five dimensions: marketing, innovation, management, risk-taking and financial control. The latter comprises six dimensions: developing new product and market opportunities, coping with unexpected challenges, developing critical human resources, defining core purposes, building an innovative environment and initiating investor relationships. The multiple-dimensional scale developed by McGee et al. (2009) and recommended for research use in the systematic literature review of Newman et al. (2019) focuses on specific entrepreneurship tasks rather than on general tasks, which have been the focus of most prior studies. The resulting process-based scale comprises the following items: searching, planning, marshaling, implementing-people and implementing-financials. In sum, existing entrepreneurial self-efficacy scales (see Table I) commonly use three common dimensions: leadership, marketing and business operations. However, the literature remains silent on whether these are directly transferable to internet entrepreneurship contexts.

\subsection{Internet entrepreneurial self-efficacy}

Understanding internet entrepreneurship (also referred to as internet ventures, digital entrepreneurship and e-commerce entrepreneurship) is a vital for information system/ information technology fields. However, research on the subject is generally lacking (Guo et al., 2016). Previous related studies are limited in number, but they share some features such as identifying an entrepreneur's abilities in marketing and business operations (such as business strategy planning, control processes, networking and target 
marketing) and leadership (shaping and maintaining a clear and consistent vision, experimenting with new product ideas and business models, being flexible to change as opportunities arise, communicating with stakeholders and making decisions) (Guo et al., 2016; Sebora et al., 2009; Wrobel, 2018) in describing internet entrepreneurial self-efficacy. These dimensions correspond to offline entrepreneurial self-efficacy dimensions, as shown in Table I. A recent study also adapted McGee et al.'s (2009) offline entrepreneurial self-efficacy scale to online contexts (Chang et al., 2018). Hence, the extant research seems to support the view that offline entrepreneurial self-efficacy is similar to online entrepreneurial self-efficacy, and these three key dimensions (i.e. leadership, marketing and business operation) of offline entrepreneurial self-efficacy are applicable to online contexts.

However, this assumption has some weaknesses, which are visible in the results of recent studies that have adapted offline scales to online contexts and have unsatisfactory model fits (SRMR larger than 0.09; Chang et al., 2018). As mentioned earlier, internet entrepreneurship has unique characteristics that existing scales do not capture. Internet entrepreneurs must design and utilize e-commerce systems (such as websites, online platforms and social media) to do business with customers (Duffy and Pruchniewska, 2017; Wang, 2008). According to e-commerce system success models (or IS success models applied in the e-commerce context), successful e-commerce systems have three qualities: system quality, service quality and information quality (DeLone and McLean, 2003, 2004; Wang, 2008). Since self-efficacy refers to people's self-perceptions of their abilities and skills in a given domain (Bandura, 2006; Wilson et al., 2007), an entrepreneur's capabilities in these three qualities needs to be incorporated into the entrepreneurial self-efficacy concept in online contexts.

System quality refers to systems (mobile apps or e-commerce websites) that facilitate customers' continuance intention and purchase intention. Internet entrepreneurs must have the capability to utilize technology to design e-commerce systems with high quality (Fang, 2017; Tseng and Lee, 2018; Wang, 2008; Wang et al., 2019).

Online customer service is another capability that internet entrepreneurs require to succeed (DeLone and McLean, 2003). Past studies on internet entrepreneurship have suggested that technology utilization and e-service are two influential factors contributing to internet venturing success. Specifically, reliability, responsiveness, ease of use and self-service positively influence e-commerce success (Sebora et al., 2009). Millman et al. (2010) indicated that with the help of web 2.0 technology, open-source software and application program interfaces, online entrepreneurs can now start and operate their businesses relatively easily.

Information quality is related to marketing (DeLone and McLean, 2003). Marketing provides needed information to customers. Past studies have indicated that the marketing dimension of offline entrepreneurial self-efficacy is directly transferrable to online contexts (Chang et al., 2018; Guo et al., 2016; Sebora et al., 2009). However, internet marketing has some distinctive features that offline marketing does not have. Internet marketing is integrated, targeted and measurable and builds and maintains relationships with customers online (Kwan et al., 2005; Wymbs, 2011). It leverages the power of online technologies (e.g. web, e-mail and databases) and new marketing strategies (e.g. viral marketing, permission marketing and search engine marketing) to create intense and profitable relationships with customers and focuses on interactivity, information and individualization (Kwan et al., 2005; Varadarajan and Yadav, 2009; Wymbs, 2011). Compared to traditional marketing, internet marketing is a more economical and faster method to create connections with consumers (Salehi et al., 2012). Existing scales of entrepreneurial self-efficacy cannot capture these new and complex forces that affect online entrepreneurial self-efficacy.

Based on the above literature review, this research defines internet entrepreneurial self-efficacy as a person's belief or confidence in one's ability to successfully launch an 
INTR

30,2

entrepreneurial venture on the internet, and comprises five dimensions with the following labels: business operation, leadership, technology utilization, online customer service and internet marketing.

\section{Hypotheses development for nomological validity test}

Based on self-efficacy theory, perceived self-efficacy has a direct effect on action and setting.

People tend to be involved in activities and behave decisively if they perceive themselves as

capable of dealing with the situation (Bandura, 1977). As such, in the context of e-commerce, when people have strong convictions regarding their effectiveness at or confidence in handling entrepreneurial activities, they tend to have high entrepreneurial intention, even if entrepreneurial activities have a high risk of failure. Past studies have revealed that individuals with higher entrepreneurial self-efficacy have higher entrepreneurial intention (Chen et al., 1998; Krueger et al., 2000; Naktiyok et al., 2010; Wilson et al., 2007). Hence, internet entrepreneurial self-efficacy should show a positive correlation with entrepreneurial intention. This prediction is stated in the following hypothesis:

H1. A positive relationship exists between internet entrepreneurial self-efficacy and entrepreneurial intention.

Based on self-efficacy theory, performance accomplishment, vicarious experience, verbal persuasion and physiological states are four major sources of information that develop perceived self-efficacy (Bandura, 1977). Among these four sources, performance accomplishment is especially influential because it is based on experiences of personal mastery. Participant modeling, such as providing relevant education, equips individuals with skills for effectively handling stressful situations (Bandura, 1977). When an individual has serviceable coping skills at their disposal, his or her sense of personal efficacy is enhanced (Bandura, 1977; Gist and Mitchell, 1992). Past studies have also indicated that training and education elevate an individual's entrepreneurial self-efficacy (Florin et al., 2007; Mueller and Goić, 2003; Zhao et al., 2005). Entrepreneurship education exposes individuals to examples of successful business planning or proactive interaction with successful practitioners, and increases entrepreneurship-related knowledge and skills (Bae et al., 2014; Martin et al., 2013). This, in turn, develops psychological coping strategies, helps maintain motivation and interest and results in higher expectations of success and greater entrepreneurial self-efficacy (Bae et al., 2014; Stumpf et al., 1987; Zhao et al., 2005). Psychological coping strategies may help individuals maintain motivation and control work or career-related anxiety, leading to higher expectations of success (Stumpf et al., 1987). In the e-commerce context, education on internet entrepreneurship equips individuals with the knowledge and skills to cope with potentially threatening situations. Educated individuals then tend to exhibit more positive efficacy expectations about internet entrepreneurship. Hence, the following hypothesis is proposed:

H2. A positive relationship exists between perceived knowledge of internet entrepreneurship and internet entrepreneurial self-efficacy.

\section{Generation of scale items}

An initial item pool for internet entrepreneurial self-efficacy scale (IESES) was created from the existing literature (Table I). The leadership and business operations dimensions used existing scales of entrepreneurial self-efficacy. For the internet marketing dimension, literature from internet marketing was consulted to develop items (Ryan, 2017; Strauss and Frost, 2014; Wymbs, 2011). Since service quality is important in the electronic commerce context (DeLone and McLean, 2003), items related to customer service were added. Additional items were collected from existing scales of computer self-efficacy pertaining to 
technology utilization (Durndell and Haag, 2002; Torkzadeh et al., 2006; Torkzadeh and Koufteros, 1994). Items capturing the ability to utilize multi-media hardware and website applications to run online businesses were developed and added to the domain of technology utilization because embedded website applications are a vital component of e-commerce websites and video is preferred by internet marketers due to positive consumer responses (Xu et al., 2015). A total of 38 items were in the initial pool, which covered the dimensions of leadership, technology utilization, online customer service, internet marketing and business operation.

Personal interviews with three management professors and three e-commerce practitioners were conducted to examine the initial pool items. These experts were asked to indicate whether any important aspects of internet entrepreneurial self-efficacy were omitted and whether the 38 items in the initial item pool adequately represented the corresponding dimensions of internet entrepreneurial self-efficacy. The experts ensured that the conceptual domain and the definition of the IESES were adequate. Based on the interviews, the business operation dimension was relabeled "e-commerce" to match the online context. One item reflecting the ability to offer cross-border electronic commerce services, and one item reflecting the ability to design e-commerce websites were added to represent the e-commerce and internet marketing dimensions, respectively. Ambiguous items (those having confusing/inappropriate wording) were identified and modified based on the consensus of the experts, resulting in the deletion of four items.

A second round of interview was conducted with two professors and one postdoctoral researcher majoring in information education. These experts were asked to assess each item based on Peterson's (2000) criteria (i.e. BRUSO): brevity, relevance, unambiguity, specificity and objectivity. Items violating the BRUSO criteria were identified and modified based on the consensus of the experts. After the two rounds of interviews, the initial item pool comprised 36 items. Seven-point Likert-scales with anchors at 1 (strongly disagree) and 7 (strongly agree) were used for responses to these items.

\section{Data collection and scale purification}

\subsection{Sample and procedure}

Online entrepreneurs were recruited from popular online platforms in Taiwan (Facebook and PPT bulletin board system). PTT is the largest terminal-based bulletin board system in Taiwan, with more than $1.5 \mathrm{~m}$ registered users and over 200,000 boards with many topics. More than 40,000 articles and $1 \mathrm{~m}$ comments are posted on a daily basis (Wei and Lu, 2013). Previous studies have collected online survey data on PTT (e.g. Su et al., 2016; Wei and Lu, 2013). A link to a questionnaire was posted on the PPT boards (e.g. toberich) and Facebook groups related to online entrepreneurship where experienced members share their knowledge and experiences with newcomers. Topics in these forums are mainly on how to use e-commerce platforms to start an online business and tips about business operations. Individuals searching for potential C2C (online auction sites such as Yahoo! Auction, eBay) or B2C (online mall platforms such as Yahoo!, Momo) online platforms for an online business were invited to participate in the online survey. These participants followed the link to the questionnaire, which had three sections: a screening question, the initial item pools and demographic items. The screening question asked participants whether they were currently searching for an online platform for their online business. Participants who were not currently seeking a platform were excluded from the analysis sample. All the items in the initial item pool were randomized to reduce response bias. A total of 359 qualified individuals followed the link to the online survey and 356 successfully completed the questionnaire. These responses were used as the analytical sample. The sample characteristics are presented in Table II. The ratio of females to males was about 3:2 (61.8 percent female; 38.2 percent male). A total of 71.1 percent of the respondents had at 


\section{INTR 30,2}

\begin{tabular}{llrr}
\hline Variable & Level & Count & Proportion (\%) \\
\hline Gender & Male & 136 & 38.2 \\
Age & Female & 220 & 61.8 \\
& 17 or below & 3 & 0.8 \\
& $18-25$ & 240 & 67.4 \\
& $26-33$ & 73 & 20.5 \\
& $34-41$ & 28 & 7.9 \\
Education & $42-49$ & 8 & 22.2 \\
& 50 or above & 4 & 1.2 \\
Occupational industry & Senior high school & 15 & 4.2 \\
& College & 253 & 71.1 \\
& Graduate school or above & 88 & 24.7 \\
& Student & 199 & 55.9 \\
& Manufacturing & 17 & 4.8 \\
& High technology & 25 & 7.0 \\
& Military services and education & 31 & 8.7 \\
& Services & 49 & 13.8 \\
& Other & 35 & 9.8
\end{tabular}

Table II.

Sample characteristics Note: $n=356$

\section{0}

least a college education, and 24.7 percent had completed graduate school or above, suggesting that most of the respondents had a high level of education. Most respondents (88.7 percent) were 33 years old or younger. The sample was varied in terms of students vs workers, with the latter involved in various industries including manufacturing, high technology, military service and education, or services.

\subsection{Test for non-response bias}

Following Armstrong and Overton (1977), a time-trend extrapolation procedure was conducted to test for non-response bias. A multivariate analysis of variance test was used to test for mean vector differences for all the items between early (first quartile) respondents and late (fourth quartile) respondents, and no significant differences were found (Wilks' $\lambda=0.543, F=1.415, p>0.05)$. As such, non-response bias is not severe.

\subsection{Reduction of the number of items}

Since a 36-item scale is relatively long, the initial item pool was reduced through statistical purification procedures (Churchill, 1979; Wang, 2003). The whole sample $(n=356)$ was randomly divided in half and the first random sample $\left(n_{1}=178\right)$ was used for the analysis.

The coefficient $\alpha$ and item-to-total correlations were calculated to delete garbage items in the first step of scale purification (Churchill, 1979; Wang, 2003). Based on the assumption that all 36 items in IESES share a common core, the coefficient $\alpha$ and item-to-total correlations were calculated for all items. The results indicated that the coefficient $\alpha$ for the IESES instrument had a reliability of 0.98 . With adequate internal reliability for the 36-item instrument, the corrected item-to-total correlation was used to delete items that had a relatively low correlation with the common core. Items with a corrected item-to-total correlation below 0.4 were eliminated (Wang, 2003). Furthermore, the corrected item-to-total correlations were plotted in descending sequence, and items whose correlations generated a substantial or sudden drop in the plotted pattern were dropped. The results revealed that the corrected item-to-total correlations were between 0.531 and 0.831 , and no substantial or sudden drops were detected from the plotted pattern. As such, no item was eliminated in this step. 
An exploratory factor analysis (EFA) was conducted to examine the factor structure of the 36-item scale. Prior to the EFA, Bartlett's sphericity test was used to investigate whether the intercorrelation matrix contains sufficient common variance to make the factor analysis viable. The significant $\chi^{2}$ value, $\chi^{2}(630)=6,127.254, p<0.001$, and the high Kaiser-Meyer-Olkin value, 0.96, support the use of EFA (Field, 2005). Following Hinkin (1998), since principal component analysis mixes common, specific and random error variances, a common factoring method such as principal axis was chosen as the extraction technique. Common factor analysis was more appropriate since the purpose was to identify underlying dimensions among the items, not data reduction (Bandalos and Boehm-Kaufman, 2009). The oblique rotation method is more appropriate than orthogonal rotation method when variables under different factors are correlated (Bandalos and Boehm-Kaufman, 2009). Since the IESES items measure perceptions and are interrelated, oblique rotation rather than orthogonal rotation was used. Both Promax and direct oblimin oblique rotation methods were used. As shown in Figure 1, both eigenvalues of greater than 1 (Kaiser's criterion) and scree plot (inflection point) were used as the rule of thumb, and resulted in three factors to be retained (Hinkin, 1998; Wang, 2003). The objective of using the EFA was to identify the items that most clearly represent the content domain of the underlying construct: items with an appropriate factor loading greater than 0.4 and/or a loading twice as strong on the appropriate factor than any other factor should be retained (Hinkin, 1998). Inappropriately loaded items are deleted, and the analysis is repeated until a clear factor structure matrix (i.e. simple factor structure) is obtained. Furthermore, the percentage of the total item variance explained should be greater than 60 percent (Hinkin, 1998).

The iterative process of EFA and item deletion resulted in a scale of 16 items representing three distinct factors, which meets the simple factor structure. The EFA results are shown in Table III. Promax rotation generated a clearer factor structure than direct oblimin, although the differences between these two rotation methods were small. The three factors explained 69.37 percent of the total item variance, which is larger than the threshold value of 60 percent. The three factors were interpreted based on their appropriately loaded items (Wang, 2003). The first factor was named "Leadership" because all items in this factor are related to the ability to lead partners and decision making for internet entrepreneurship. Since all items in the second factor are related to the ability to use computers, multi-media facilities or website tools to help facilitate internet entrepreneurship, this factor was called "Technology Utilization." During the EFA process, items intended to measure "Internet Marketing" and "E-Commerce" were highly correlated, so these two factors were merged, resulting in a factor called "Internet Marketing and E-Commerce." Internet marketing and e-commerce are part of e-business (Salehi et al., 2012; Strauss and Frost, 2014). They are highly intertwined and interchangeable (Varadarajan and Yadav, 2009). Items intended to load on "Online Customer Service" are also loaded on "Internet Marketing and E-Commerce." Since the role of online customer service has been increasing with the rise

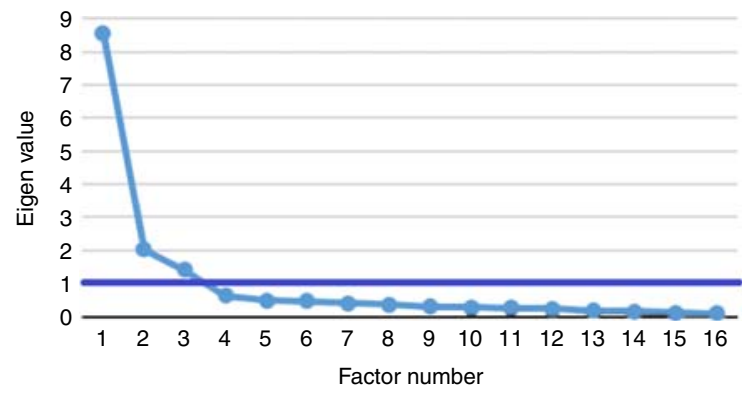

Figure 1 . Kaiser's criterion and the scree plot 


\begin{tabular}{|c|c|c|c|c|}
\hline \multirow{2}{*}{$\begin{array}{l}\text { INTR } \\
30,2\end{array}$} & \\
\hline & Item code & Leadership & Technology utilization & Internet marketing and e-commerce \\
\hline \multirow{15}{*}{662} & A1 & $0.60 / 0.59$ & $0.02 /-0.03$ & $0.19 / 0.20$ \\
\hline & $\mathrm{A} 2^{\mathrm{a}}$ & $0.85 / 0.83$ & $-0.13 / 0.11$ & $0.15 / 0.17$ \\
\hline & $\mathrm{A} 3$ & $0.84 / 0.82$ & $-0.00 /-0.01$ & $-0.01 /-0.05$ \\
\hline & $\mathrm{A} 4$ & $0.76 / 0.74$ & $0.05 /-0.05$ & $-0.09 /-0.07$ \\
\hline & A5 & $0.67 / 0.65$ & $0.14 /-0.14$ & $-0.06 /-0.03$ \\
\hline & B1 & $-0.03 /-0.01$ & $0.88 /-0.85$ & $-0.02 /-0.01$ \\
\hline & $\mathrm{B} 2^{\mathrm{a}}$ & $-0.12 /-0.10$ & $0.98 /-0.95$ & $0.05 / 0.09$ \\
\hline & B3 & $0.17 / 0.18$ & $0.79 /-0.76$ & $-0.02 / 0.01$ \\
\hline & B4 & $0.18 / 0.19$ & $0.69 /-0.67$ & $0.02 / 0.05$ \\
\hline & $\mathrm{C} 1$ & $0.03 / 0.04$ & $-0.04 / 0.02$ & $0.84 / 0.82$ \\
\hline & $\mathrm{C} 2$ & $0.02 / 0.04$ & $0.00 /-0.02$ & $0.82 / 0.80$ \\
\hline & C3 & $0.02 / 0.03$ & $0.03 /-0.05$ & $0.81 / 0.80$ \\
\hline & D1 & $0.07 / 0.08$ & $0.07 /-0.09$ & $0.79 / 0.78$ \\
\hline & $\mathrm{D} 2^{\mathrm{a}}$ & $-0.07 /-0.05$ & $0.11 /-0.12$ & $0.86 / 0.84$ \\
\hline & D3 & $-0.10 /-0.08$ & $0.12 /-0.14$ & $0.86 / 0.84$ \\
\hline T 1 TI & $\mathrm{D} 4$ & $0.02 / 0.02$ & $-0.17 / 0.14$ & $0.86 / 0.84$ \\
\hline
\end{tabular}

Rotated factor loadings for the 16-item instrument (Sample 1)

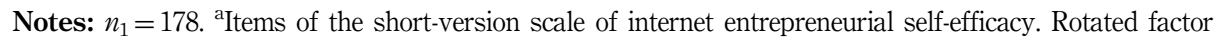
loadings for Promax/direct oblimin methods; principal axis as common factoring method. A1-A5 reflect the leadership dimension; B1-B4 reflect the technology utilization dimension; C1-C3 and D1-D4 reflect the internet marketing and e-commerce dimension

of electronic commerce (DeLone and McLean, 2003) and the development of long-term customer relationship is a key marketing activity for internet startups (Wrobel, 2018), it is not surprising that these items were relatively highly loaded on "Internet Marketing and E-Commerce." These items were all deleted due to cross-loading issues. The resulting 16-item scale achieved unidimensionality, since all items loaded on the single factor. Discriminant validity of the 16 -item scale was achieved because no serious cross-loading items were noted.

\subsection{Internal consistency assessment}

Evaluations of the reliability of the developed scale were measured with Cronbach's $\alpha$, which assesses the internal consistency of the items representing each factor. The 16-item scale had a Cronbach's $\alpha$ value of 0.94 , exceeding the threshold value of 0.70 (Nunnally, 1978). Reliabilities for each factor were acceptable. The $\alpha$ coefficients for leadership $(\alpha=0.87)$, technology utilization $(\alpha=0.92)$ and internet marketing and e-commerce $(\alpha=0.95)$ all exceeded the threshold value (i.e. 0.70$)$, which indicates acceptable reliability. Furthermore, as shown in Table IV, the corrected item-to-total correlations for all 16 items exceeded 0.40 (Wang, 2003).

\subsection{Convergent and discriminant validity}

Following Wang (2003), the convergent and discriminant validity of the 16 -item scale was assessed using a correlation matrix. Convergent validity determines whether the correlations between measures of the same factor are significantly different from 0 and of sufficient size. As shown in Table V, all the within-factor correlations are significantly different from 0 ( $p$-values $<0.001)$, and the smallest within-factor correlations are leadership (0.48), technology utilization (0.67) and internet marketing and e-commerce (0.60). As such, the results suggest the attainment of convergent validity. Discriminant validity for each item was assessed by calculating the number of times that the item has higher correlation with items from other factors than with items from its own theoretical factor. The results, shown in Table V, indicate only one violation of discriminant validity 


\begin{tabular}{|c|c|c|c|c|}
\hline $\begin{array}{l}\text { Item } \\
\text { code }\end{array}$ & Item & $\begin{array}{l}\text { Corrected item- } \\
\text { to-total } \\
\text { correlation }\end{array}$ & Item source & $\begin{array}{l}\text { entrepreneurial } \\
\text { self-efficacy }\end{array}$ \\
\hline $\mathrm{A} 1^{\mathrm{b}}$ & I possess the ability to be a leader & 0.63 & Wilson et al. (2007) & scale \\
\hline $\mathrm{A} 2^{\mathrm{a}, \mathrm{b}}$ & $\begin{array}{l}\text { I can make others agree with } \\
\text { my thoughts }\end{array}$ & 0.67 & Wilson et al. (2007) & \\
\hline $\mathrm{A} 3^{\mathrm{b}}$ & $\begin{array}{l}\text { I can find work partners who } \\
\text { complement my ability }\end{array}$ & 0.55 & De Noble et al. (1999) & 663 \\
\hline $\mathrm{A} 4^{\mathrm{b}}$ & $\begin{array}{l}\text { I can have pleasant conversations with } \\
\text { my work partners }\end{array}$ & 0.52 & McGee et al. (2009) & \\
\hline $\mathrm{A} 5^{\mathrm{b}}$ & $\begin{array}{l}\text { I have the ability to make decisions after } \\
\text { deliberation }\end{array}$ & 0.56 & Wilson et al. (2007) & \\
\hline $\mathrm{B} 1^{\mathrm{b}}$ & $\begin{array}{l}\text { I have a basic ability in computer file } \\
\text { management }\end{array}$ & 0.64 & $\begin{array}{l}\text { Durndell and Haag (2002), Torkzadeh et al. } \\
\text { (2006), Torkzadeh and Koufteros (1994) }\end{array}$ & \\
\hline $\mathrm{B} 2^{\mathrm{a}, \mathrm{b}}$ & $\begin{array}{l}\text { I can install and manipulate basic types of } \\
\text { computer hardware to help my business }\end{array}$ & 0.71 & $\begin{array}{l}\text { Durndell and Haag (2002), Torkzadeh } \\
\text { et al. (2006), Torkzadeh and Koufteros } \\
\text { (1994) }\end{array}$ & \\
\hline B3 & $\begin{array}{l}\text { I can use multi-media hardware to help } \\
\text { my business }\end{array}$ & 0.72 & Newly developed & \\
\hline B4 & $\begin{array}{l}\text { I have the ability to install and use } \\
\text { website applications }\end{array}$ & 0.70 & Newly developed & \\
\hline $\mathrm{C} 1$ & $\begin{array}{l}\text { I can formulate an innovative internet } \\
\text { marketing strategy (such as viral } \\
\text { marketing) }\end{array}$ & 0.73 & Newly developed & \\
\hline $\mathrm{C} 2$ & $\begin{array}{l}\text { I can create a unique electronic commerce } \\
\text { website }\end{array}$ & 0.74 & Newly developed & \\
\hline C3 & $\begin{array}{l}\text { I know how to formulate a pricing } \\
\text { strategy for my e-shop }\end{array}$ & 0.76 & Newly developed & \\
\hline $\mathrm{D} 1^{\mathrm{b}}$ & $\begin{array}{l}\text { I can analyze the cost structure of } \\
\text { my e-shop }\end{array}$ & 0.81 & Chen et al. (1998), McGee et al. (2009) & \\
\hline $\mathrm{D} 2^{\mathrm{a}, \mathrm{b}}$ & $\begin{array}{l}\text { I can propose a profitable business model } \\
\text { for electronic commerce }\end{array}$ & 0.79 & Newly developed & \\
\hline $\mathrm{D} 3^{\mathrm{b}}$ & $\begin{array}{l}\text { I can easily gain access to the resources } \\
\text { needed to operate my e-shop }\end{array}$ & 0.78 & De Noble et al. (1999) & \\
\hline D4 & $\begin{array}{l}\text { I can solve tariff problems pertaining to } \\
\text { importing and exporting }\end{array}$ & 0.63 & Newly developed & Table IV. \\
\hline \multicolumn{4}{|c|}{$\begin{array}{l}\text { Notes: } n_{1}=178 \text {. Items of the short-version scale of internet entrepreneurial self-efficacy. }{ }^{\text {b Items adapted }} \\
\text { from previous scales. A1-A5 reflect the leadership dimension; B1-B4 reflect the technology utilization } \\
\text { dimension; C1-C3 and D1-D4 reflect the internet marketing and e-commerce dimension }\end{array}$} & $\begin{array}{l}\text { Corrected item-to-total } \\
\text { correlations of IESES } \\
\text { measures (Sample 1) }\end{array}$ \\
\hline
\end{tabular}

(correlation between A1 and C1), which is acceptable according to Wang (2003). Thus, discriminant validity is achieved.

\subsection{Criterion-related validity}

To determine criterion-related validity, the correlations between the average score on the 16-item scale and the measure of the valid criterion, and the correlations between the measure of the valid criterion and the average scores of the three dimensions of the scale were analyzed. The criterion used in this study was one global item of internet entrepreneurial self-efficacy: "Overall, I feel very confident about e-commerce entrepreneurship." A positive correlation was anticipated between the average score on the 16-item scale and the score of the global item if the 16-item scale was capable of measuring internet entrepreneurial self-efficacy. The results indicate that the correlation coefficient is positive and significant $(r=0.80, p<0.001)$. Furthermore, a valid criterion is expected to correlate with the average scores of the three dimensions of internet 
INTR

30,2

664

Table V.

Correlation matrix of measures (Sample 1)

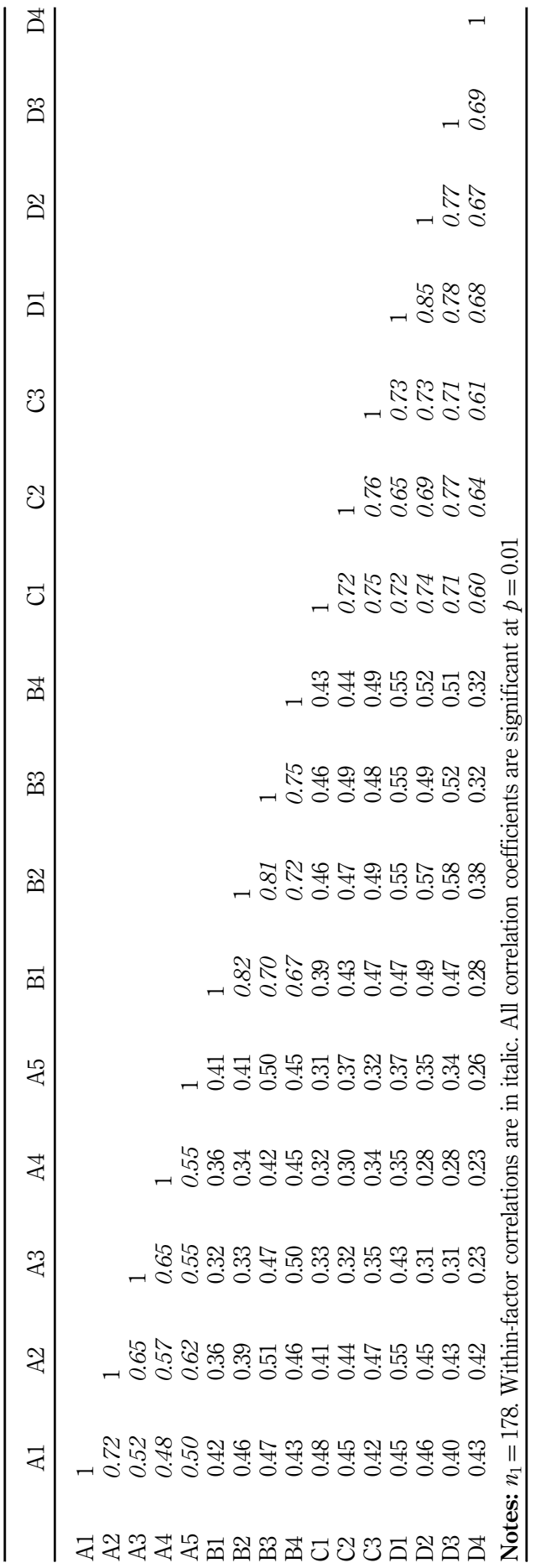


entrepreneurial self-efficacy. The results reveal that the criterion had positively significant correlations with leadership $(r=0.51, p<0.001)$, technology utilization $(r=0.55, p<0.001)$ and internet marketing and e-commerce $(r=0.85, p<0.001)$. These results suggest that the new scale demonstrates acceptable criterion-related validity.

\subsection{Nomological validity}

Following Hinkin (1998), a nomological network was developed to hypothesize the relationships between the IESES and the theoretically related variables from existing theory. The items used for examining nomological validity and the corresponding Cronbach's $\alpha$ values are shown in Table VI. To test H1, three items for measuring entrepreneurial intention were adapted from Top et al. (2012). To test H2, measures of internet entrepreneurship knowledge were determined by participants in the second round of expert interviews. These measures reflect different facets of internet entrepreneurship, including electronic law, common knowledge, computer ability, internet marketing and e-commerce. Correlation analysis was then conducted to investigate whether the hypothesized relationships were supported.

The results of the correlation analysis indicate that the average IESES score was significantly and positively correlated with the average score of entrepreneurial intention $(r=0.61, p<0.001)$. Furthermore, the correlation coefficients between entrepreneurial intention and the three IESES dimensions (i.e. leadership, technology utilization and internet marketing and e-commerce) were all positive (i.e. 0.40, 0.34 and 0.68) and significant ( $p$-values $<0.001$ ). Thus, $H 1$ is supported. The average IESES score positively correlated with the average score of internet entrepreneurship knowledge $(0.89, p<0.001)$. Furthermore, the average scores of each IESES dimension correlated positively with the average score of internet entrepreneurship knowledge. Specifically, the average score of the IESES leadership dimension positively correlated with the average score of internet entrepreneurship knowledge $(0.63, p<0.001)$; the average score of the IESES technology utilization dimension positively correlated with the average score of internet entrepreneurship knowledge $(0.72, p<0.001)$; and the mean score of the IESES internet marketing and e-commerce dimension positively correlated with the mean score of internet entrepreneurship knowledge $(0.85, p<0.001)$. As such, $H 2$ is supported.

Based on the above results, nomological validity of IESES is empirically supported.

\subsection{A short scale of internet entrepreneurial self-efficacy}

The above results indicate that IESES achieved adequate reliability, convergent validity, discriminant validity, criterion-related validity and nomological validity. Furthermore, the multi-dimensional nature of IESES suggests high diagnosticity. Specifically, in addition to the overall score of internet entrepreneurial self-efficacy, IESES can show the scores of its dimensions.

\begin{tabular}{|c|c|c|c|}
\hline Item & Cronbach $\alpha$ values & Item source & \\
\hline $\begin{array}{l}\text { Entrepreneurial intention } \\
\text { I predict that one day I will set up my own e-commerce business } \\
\text { I am determined to start a business on the internet in the future } \\
\text { I am very serious about setting up an e-commerce business }\end{array}$ & 0.96 & $\begin{array}{l}\text { Adapted from } \\
\text { Top et al. (2012) }\end{array}$ & \\
\hline $\begin{array}{l}\text { Internet entrepreneurship knowledge } \\
\text { I have basic common sense and knowledge regarding electronic law } \\
\text { I understand basic website design } \\
\text { I know how to formulate a marketing channel strategy for an e-shop } \\
\text { I know how to offer the target market products that meet their needs }\end{array}$ & 0.81 & Self-developed & $\begin{array}{r}\text { Table VI. } \\
\text { Items for examining } \\
\text { nomological validity } \\
\text { and construct } \\
\text { reliability }\end{array}$ \\
\hline
\end{tabular}


INTR 30,2

\section{6}

Table VII.

Correlation matrix and descriptive statistics of the constructs (Sample 2)
Although the results show that IESES had adequate psychometric properties and diagnosticity, a scale with 16 items is relatively inefficient for practical use if the main purpose is to investigate the overall level of internet entrepreneurial self-efficacy, rather than the scores of its dimensions. As such, a short scale of internet entrepreneurial self-efficacy was developed. To achieve a parsimonious scale, the item with the highest factor loading was selected as a surrogate variable to represent each dimension of online entrepreneurial self-efficacy (Hair et al., 2010, p. 123). Hence, A2, B2 and D2 were selected to represent "Leadership," "Technology Utilization" and "Internet Marketing and E-Commerce," respectively (see Table III).

The psychometric properties of the three-item short scale were examined. The Cronbach's $\alpha$ value for the short scale exceeded 0.70 (i.e. 0.75), indicating acceptable internal consistency reliability (Nunnally, 1978). The average score for the three-item short scale had a very high correlation with the average IESES score $(r=0.93, p<0.001)$, which suggests that information lost to scale parsimony was not severe, and further justifies the use of the short scale. Furthermore, the short scale has adequate criterion-related validity because it correlated positively with the criterion $(r=0.70, p<0.001)$. Finally, the nomological validity of the short scale was achieved because it correlated positively with both internet entrepreneurship knowledge $(r=0.81, p<0.001)$ and entrepreneurial intention $(r=0.57$, $p<0.001)$. In sum, the short scale of internet entrepreneurial self-efficacy consisted of three items and exhibited adequate psychometric properties.

\subsection{Confirmatory factor analysis}

A confirmatory factor analysis was conducted to further validate the factor structure derived from EFA (Hinkin, 1998). The second half of the random sample $\left(n_{2}=178\right)$ was used for the analysis. The threshold values of RMSEA $\leqslant 0.08$, SRMR $\leqslant 0.10, \mathrm{CFI} \geqslant 0.9$ and NNFI $\geqslant 0.9$ are recommended (Hair et al., 2010; Bentler and Bonett, 1980). Composite reliability (CR) was used as a reliability measure. The threshold value for CR is 0.70 (Hair et al., 2010). Convergent validity is achieved if the average variance extracted (AVE) estimates for all constructs are all greater than 0.50 (Fornell and Larcker, 1981) and if all the item loadings are significant (Anderson and Gerbing, 1988). Discriminant validity is achieved if the $95 \%$ confidence interval around the correlation between the two constructs does not include one (Anderson and Gerbing, 1988). Alternatively, if AVE estimates for a given pair of constructs are all greater than the square of the construct correlation, discriminant validity is supported (Fornell and Larcker, 1981).

The CFA results are shown in Tables VII and VIII. The model fit of the three-factor model derived from EFA is acceptable in CFA $\left(\chi^{2}=206.29 ; \mathrm{df}=101 ; p<0.001 ; \chi^{2} / \mathrm{df}=2.04\right.$; $\mathrm{CFI}=0.97 ; \mathrm{NNFI}=0.96$; $\mathrm{RMESA}=0.077$; $\mathrm{SRMR}=0.063)$. All $\mathrm{CR}$ values are greater than 0.70 , indicating adequate construct reliability. The standardized item loadings are all significant $(p<0.001)$ and all AVE estimates surpass 0.50, supporting convergent validity. Moreover, none of the $95 \%$ confidence intervals for the construct correlation

\begin{tabular}{lccc}
\hline Construct & 1 & 2 & 3 \\
\hline 1. Leadership & 0.51 & & \\
2. Technology utilization & $0.36(0.08)$ & 0.67 & \\
3. Internet marketing and e-commerce & $0.40(0.07)$ & $0.46(0.07)$ & 0.65 \\
Mean & 5.09 & 5.39 & 4.25 \\
SD & 0.82 & 1.06 & 1.18
\end{tabular}

Notes: $n_{2}=178$. Standard errors are in parentheses. The values on the diagonal (in italic) are average variance extracted (AVE) estimates 
Item

Leadership $(\alpha=0.83, C R=0.84)$

A1

A2

A3

A4

A5

Technology utilization $(\alpha=0.89, C R=0.89)$

B1

B2

B3

B4

Internet marketing and e-commerce $(\alpha=0.93, C R=0.93)$

$\mathrm{C} 1$

$\mathrm{C} 2$

C3

D1

D2

D3

D4

Notes: $n_{2}=178$. Standardized loadings are reported. $* * * p<0.001$
Factor loading

$0.71 * * *$

$0.81 * * *$

$0.64 * * *$

$0.67^{* * * *}$

$0.71^{* * *}$

$0.83 * * *$

$0.80^{* * * *}$

$0.86^{* * *}$

$0.79 * * *$

$0.77 * * * *$

0.71 ****

$0.76^{* * * *}$

$0.90 * * *$

$0.91 * * *$

$0.84^{* * *}$

$0.73 * * * *$
Internet

entrepreneurial self-efficacy

scale

667

estimates includes 1 , and the square of estimates of the construct correlation is smaller than the corresponding AVE estimates for all pairs of constructs. Thus, discriminant validity is achieved.

Aside from the three-factor model, different combinations of factor structure were examined. The one-factor model had poor fit $\left(\chi^{2}=1,002.28 ; \mathrm{df}=104 ; p<0.001 ; \chi^{2} / \mathrm{df}=9.64\right.$; $\mathrm{CFI}=0.81 ; \mathrm{NNFI}=0.78 ; \mathrm{RMESA}=0.22 ; \mathrm{SRMR}=0.16)$ and thus IESES is not unidimensional but multi-dimensional. Although the four-factor model had a better fit $\left(\chi^{2}=186.31 ; \mathrm{df}=98 ; p<0.001 ; \chi^{2} / \mathrm{df}=1.90 ; \mathrm{CFI}=0.97 ; \mathrm{NNFI}=0.97 ; \mathrm{RMESA}=0.071\right.$; $\mathrm{SRMR}=0.058)$ than the three-factor model, the correlation between internet marketing factor and e-commerce factor was very high (i.e. 0.93 ). The poor discriminant validity makes the four-factor model unfeasible. Thus, the data support the three-factor model derived from EFA. Furthermore, the data also support the use of a higher order model with three sub-dimensions $\left(\chi^{2}=206.29 ; \mathrm{df}=101 ; p<0.001 ; \chi^{2} / \mathrm{df}=2.04 ; \mathrm{CFI}=0.97 ; \mathrm{NNFI}=0.96\right.$; $\mathrm{RMESA}=0.077 ; \mathrm{SRMR}=0.063)$.

Regarding nomological validity, the results of Sample 2 are consistent to Sample 1. Specifically, the average IESES score correlates positively with internet entrepreneurship knowledge $(r=0.80, p<0.001)$ and entrepreneurial intention $(r=0.59, p<0.001)$. Furthermore, entrepreneurial intention positively correlates with IESES dimensions leadership $(r=0.30, p<0.001)$, technology utilization $(r=0.21, p<0.001)$ and internet marketing and e-commerce $(r=0.68, p<0.001)$. Internet entrepreneurship knowledge positively correlates with IESES dimensions leadership $(r=0.35, p<0.001)$, technology utilization $(r=0.56, p<0.001)$ and internet marketing and e-commerce $(r=0.79, p<0.001)$.

\section{Discussion}

This study developed a IESES using established scale development procedures (Churchill, 1979; Hinkin, 1998; Wang, 2003). The results reveal that IESES is composed of three dimensions: leadership, technology utilization and internet marketing and e-commerce. The scale has adequate content validity and reliability according to the procedures recommend 
INTR

30,2

by Churchill (1979), including specifying the domain of the constructs, generating items that exhaust the domain and purifying the resulting scale (Wang, 2003). Furthermore, the convergent validity, discriminant validity and criterion-related validity of IESES were empirically confirmed. The scale also has nomological validity because it correlates positively with internet entrepreneurship knowledge and entrepreneurial intention. Moreover, IESES can be generalized to different gender and occupational groups, and has external validity. A short three-item IESES demonstrated adequate psychometric properties. Use of either IESES or its short version depends on the purpose of the investigation. If the purpose is to investigate the overall level of internet entrepreneurial self-efficacy, the short version is the most efficient. If a detailed diagnosis of a person's internet entrepreneurial self-efficacy is required, IESES can be utilized.

\subsection{Theoretical implications}

The results of this study support the application of self-efficacy theory in the context of internet entrepreneurship. Specifically, internet entrepreneurial self-efficacy positively correlates with entrepreneurial intention, which is consistent with past studies (Chen et al., 1998; Krueger et al., 2000; Naktiyok et al., 2010; Wilson et al., 2007). Furthermore, one influential antecedent of self-efficacy is personal accomplishment. The current study used internet entrepreneurship knowledge to represent personal accomplishment because internet entrepreneurship knowledge is positively related to personal mastery experiences, which is a key driver of personal accomplishment (Bandura, 1977). The results of this study indicate that internet entrepreneurship knowledge is positively correlated with internet entrepreneurial self-efficacy, which aligns well with self-efficacy theory (Bandura, 1977). The results also correspond to previous findings that suggested entrepreneurial education is one influential antecedent of entrepreneurial self-efficacy (Florin et al., 2007; Mueller and Goić, 2003; Zhao et al., 2005). Entrepreneurial knowledge is conceptually related to entrepreneurial education. However, this current study differs from past studies by testing self-efficacy theory in the context of online entrepreneurship. Past studies indicated that leadership (e.g. marshaling and risk-taking) has a relatively stronger influence on offline entrepreneurship (Chen et al., 1998; McGee et al., 2009). However, the results of the current study show that compared to the internet marketing and e-commerce and technology utilization dimensions, leadership has the least effect on entrepreneurship in the online context. The ability to do internet marketing and e-commerce is important in the online context since the success of cyber entrepreneurship depends on whether entrepreneurs have adequate digital marketing skills (Entrepreneur India, 2018). The leadership dimension has less of a role to play in the online entrepreneurship contexts because many team members may be geographically dispersed (Kerr and Jermier, 1978).

Self-efficacy theory posits a general dimension of self-efficacy expectation. Self-efficacy expectation can be general across different contexts or specific to a certain context (Bandura, 1977). Past studies have indicated that self-efficacy in the context of entrepreneurship is specific and multi-dimensional (Barbosa et al., 2007; Chen et al., 1998; De Noble et al., 1999; McGee et al., 2009; Naktiyok et al., 2010). This study corroborates this finding in the online entrepreneurship context. However, this study differs from past studies, which focused on the personal dimension of entrepreneurial self-efficacy. Both technical (i.e. technology utilization) and personal dimensions (i.e. leadership and internet marketing and e-commerce) of self-efficacy have to be considered in the internet entrepreneurship context. The integration of personal and the technical self-efficacy expectations comprise internet entrepreneurial self-efficacy, which deserves further examination. Future studies can utilize dynamic capability theory that stresses the importance of integration of different capabilities (Agarwal and Selen, 2009) to explore how to integrate different technical and personal capabilities to enhance internet entrepreneurial self-efficacy perceptions. 
Although a recent study indicated that the dimensions of entrepreneurial self-efficacy in the offline context can be directly transferred to the online context (Chang et al.,2018) by adapting McGee et al.'s (2009) scale, the current findings provide a contrasting view. Although there is some overlap of the underlying dimensions of internet entrepreneurial self-efficacy and entrepreneurial self-efficacy (i.e. leadership), the dimensions of entrepreneurial self-efficacy are unable to fully capture internet entrepreneurial self-efficacy. The technology utilization and internet marketing and e-commerce dimensions are key contributions of the current study. Internet entrepreneurs have to believe they have the ability to utilize IT-related technology to aid their online businesses. This is corroborated in recent studies, indicating that online entrepreneurs use social media, mobile or Internet-of-Things technologies to start their online businesses (Duffy and Pruchniewska, 2017; Wing-Fai, 2016; Yu et al., 2017). The technology utilization dimension is different from computer efficacy because the conceptual domain of the former is larger than the latter. Other than abilities to use computers (e.g. file management and computer facilities), abilities to install and use website applications and multi-media facilities are also included.

The internet marketing and e-commerce dimension of internet entrepreneurial self-efficacy is different from the marketing dimension in the offline entrepreneurial self-efficacy scale. Internet marketing applies information technology to traditional marketing and the use of technology transforms many marketing strategies, such as viral marketing and searching engine marketing (Strauss and Frost, 2014). The technology component allows marketers to use new and varied platforms to connect with consumers in increasingly diverse and relevant ways. Marketers can leverage technology to communicate with consumers more effectively and efficiently (Ryan, 2017). Compared to the business operation dimension in the offline entrepreneurial self-efficacy scale, business operations in the online entrepreneurial self-efficacy scale focuses more on e-commerce. Cross-border e-commerce is included in the conceptual domain of e-commerce to reflect the globalized character of online businesses.

In conclusion, the conceptual domain of internet entrepreneurial self-efficacy is different from offline entrepreneurial self-efficacy and thus the direct application or the adaptation of offline entrepreneurial self-efficacy scale to the online context can cause content validity concerns. This study responds to Newman et al. (2019) by developing new measures of entrepreneurial self-efficacy, ranked in terms of increasing importance (i.e. internet entrepreneurship). Furthermore, the findings of this study reveal the relative importance of the dimensions of internet entrepreneurial self-efficacy in facilitating entrepreneurial intention (i.e. internet marketing and e-commerce $>$ technology utilization $>$ leadership). The internet marketing and e-commerce dimension is the most effective. This is consistent to Wrobel (2018) - competences related to marketing and sales are the most relevant for internet entrepreneurs. However, this study differs from Wrobel (2018) by showing that internet marketing competences are more relevant than marketing competences in internet entrepreneurship contexts. Technology utilization is less effective than internet marketing and e-commerce. This corroborates Ryan's (2017) findings that the personal component is more important than the technical component in digital marketing. The leadership dimension is the least important dimensions, which is a very different from offline entrepreneurial self-efficacy (Chen et al., 1998; McGee et al., 2009).

\subsection{Managerial implications}

The results indicate that internet entrepreneurship knowledge correlates positively with internet entrepreneurial self-efficacy, and internet entrepreneurial self-efficacy correlates positively with entrepreneurial intention. As such, governments can encourage universities and employment counseling agencies to offer relevant courses on internet entrepreneurship to enhance people's perceived self-efficacy, which, in turn, can boost rates of internet entrepreneurship. Course design should focus on the three facets of internet entrepreneurial self-efficacy: leadership, technology utilization and internet marketing and e-commerce. 
INTR 30,2

For courses on leadership development, effective communication and decision making should be emphasized. To improve technology utilization, courses on file management, computer hardware, multi-media hardware and website applications that aid internet entrepreneurs should be offered. To improve capabilities in internet marketing and e-commerce, courses should focus on internet marketing strategies (e.g. viral marketing and search engine marketing), pricing strategies, internet channel strategies, cost structure analysis, electronic business models, resource acquisition and cross-border electronic commerce. One key difference between internet entrepreneurship and offline entrepreneurship is the use of information technology. Many courses on internet entrepreneurship have focused on the technology component (e.g. programming languages and techniques such as Python and R). However, internet entrepreneurship is about both the technical and the personal (i.e. leadership and internet marketing and e-commerce). As such, course designers should not focus too much on the technology and instead cover both the technical and personal components.

Furthermore, government authorities can capitalize on the multi-dimensional nature of IESES to aid in resource allocation pertaining to course design. Specifically, they can conduct a national IESES to learn about the relative importance of the three dimensions of internet entrepreneurial self-efficacy in relation to entrepreneurial intention among potential entrepreneurs. Resource allocation guidelines for course arrangement can then be developed. As for the results of this study, since the correlation coefficient between internet marketing and e-commerce and entrepreneurial intention was relatively strong, more courses related to internet marketing and e-commerce should be provided to potential entrepreneurs.

Many online platforms, such as Yahoo! Auctions and Shopee Auctions, offer courses to attract potential entrepreneurs to start businesses using their online platforms. The results of the current study can help online platforms develop and offer courses that better meet the needs of internet entrepreneurs. Specifically, online platforms can put the new scale (i.e. IESES) developed in this study on their platforms and provide an online service that helps potential entrepreneurs self-evaluate their abilities in internet entrepreneurship. The online service can help potential entrepreneurs understand their scores on the three dimensions of internet entrepreneurial self-efficacy, identify deficiencies, and then recommend relevant courses to attend.

Since the short scale of internet entrepreneurial self-efficacy correlated positively with entrepreneurial intention, universities can use this scale as a proxy to quickly identify whether a student intends to start an online business in the future. An individual whose score on the short scale is above average can be identified as a potential entrepreneur, and be sent information on courses, lectures and resources related to online entrepreneurship.

The short scale can also be a useful tool for consulting services and online education companies to identify potential target markets. Individuals seeking jobs often browse human-resource agency websites, so companies can place advertisements on agency websites with copy such as, "Do you want to work for others, or create your own online business? Complete a one-minute test to know whether you can be the boss of your online business." Respondents who score high on the short scale can be encouraged with messages such as, "You are a natural online entrepreneur. We expect to see you successfully operating an online business in the near future." These high-scoring respondents might have a need for consulting services to help facilitate online entrepreneurship. Low-scoring respondents can be invited to the company's website to participate in a deep diagnosis on internet entrepreneurship. The 16-item multi-dimensional IESES can be offered to these respondents and the results can help identify respondents' weaknesses, which can be used to suggest relevant courses to attend. For instance, if a respondent has high scores on technology utilization and internet marketing and e-commerce, but a low score on leadership, courses on interpersonal communication and decision making can be promoted. Completion of relevant courses can boost low-scoring respondents' online entrepreneurship abilities. 

hard to obtain, a purposive sampling methodology was used to collect data from individuals with knowledge and experience in internet entrepreneurship. As a result, the sample was generally young (67.4 percent between 18 and 25 years old), relatively well-educated (71.1 percent had college education) and currently studying (55.9 percent). This is not a serious concern about sample representativeness because students in Taiwan are increasingly engaged in internet entrepreneurship and many universities have collaborated with digital companies to introduce learning-by-doing courses teaching students how to open their online businesses on electronic platforms (Epoch Times, 2017). Furthermore, the sample was randomly divided in half and the findings were consistent across both sides, which show sample generalizability. Nevertheless, future studies should further test the scale with samples of different ages, levels of education and employment backgrounds.

The current study and other cyber entrepreneurship studies were conducted in Taiwan (Chang et al., 2018; Wang et al., 2016). The dimensions of internet entrepreneurial self-efficacy including leadership, technology utilization and internet marketing and e-commerce were designed to be applicable to other countries and cultures. Therefore, future studies can empirically test the factor structure of IESE in different countries and cultures.

The main purpose of this paper was to propose a valid scale for internet entrepreneurial self-efficacy, not to develop the nomological network. Future studies should use the new scale as a basis to develop and test a more comprehensive nomological network. The current study examined the relationship between internet entrepreneurial self-efficacy and entrepreneurial intention, and the focus was on behavioral intention rather than entrepreneurial behavior. An interesting avenue for future research is to examine whether internet entrepreneurial self-efficacy is associated with different types of entrepreneurial activities. A longitudinal design should be utilized to examine this issue because entrepreneurial activities are likely to be sequential, not concurrent. Furthermore, this study examined one antecedent of internet entrepreneurial self-efficacy (internet entrepreneurship knowledge). Future studies can examine how internet entrepreneurial self-efficacy is related to individual characteristics (e.g. locus of control and self-esteem).

\section{References}

Agarwal, R. and Selen, W. (2009), "Dynamic capability building in service value networks for achieving service innovation”, Decision Sciences, Vol. 40 No. 3, pp. 431-475.

Anderson, J.C. and Gerbing, D.W. (1988), "Structural equation modeling in practice: a review and recommended two-step approach", Psychological Bulletin, Vol. 103 No. 3, pp. 411-423.

Armstrong, J.S. and Overton, T.S. (1977), "Estimating nonresponse bias in mail surveys", Journal of Marketing Research, Vol. 14 No. 3, pp. 396-402.

Bae, T.J., Qian, S., Miao, C. and Fiet, J.O. (2014), “The relationship between entrepreneurship education and entrepreneurial intentions: a meta-analytic review", Entrepreneurship Theory and Practice, Vol. 38 No. 2, pp. 217-254.

Bandalos, D.L. and Boehm-Kaufman, M.R. (2009), "Four common misconceptions in exploratory factor analysis", in Lance, C.E. and Vandenberg, R.J. (Eds), Statistical and Methodological Myths and Urban Legends, Routledge, New York, NY, pp. 61-88.

Bandura, A. (1977), "Self-efficacy: toward a unifying theory of behavioral change", Psychological Review, Vol. 84 No. 2, pp. 191-215.

Bandura, A. (1997), Self-Efficacy: The Exercise of Control, Freeman, New York, NY.

Bandura, A. (2006), "Guide for constructing self-efficacy scales", in Pajares, F. and Urdan, T. (Eds), Self-Efficacy Belief and Adolescence, Information Age, Greenwich, CT, pp. 307-337. 
INTR 30,2

Barbosa, S.D., Gerhardt, M.W. and Kickul, J.R. (2007), "The role of cognitive style and risk preference on entrepreneurial self-efficacy and entrepreneurial intentions", Journal of Leadership \& Organizational Studies, Vol. 13 No. 4, pp. 86-104.

Bentler, P.M. and Bonett, D.G. (1980), "Significance tests and goodness of fit in the analysis of covariance structures", Psychological Bulletin, Vol. 88 No. 3, pp. 588-606.

Boyd, N.G. and Vozikis, G.S. (1994), "The influence of self-efficacy on the development of entrepreneurial intentions and actions", Entrepreneurship Theory and Practice, Vol. 18 No. 4, pp. 63-63.

Cardon, M.S. and Kirk, C.P. (2015), "Entrepreneurial passion as mediator of the self-efficacy to persistence relationship", Entrepreneurship Theory and Practice, Vol. 39 No. 5, pp. 1027-1050.

Chang, S.H., Wang, C.L., Lee, J.C. and Yu, L.C. (2018), "Who needs entrepreneurial role models? Driving forces of students' cyber-entrepreneurial career Intention", EURASIA Journal of Mathematics, Science and Technology Education, Vol. 14 No. 7, pp. 3083-3098.

Chen, C.C., Greene, P.G. and Crick, A. (1998), "Does entrepreneurial self-efficacy distinguish entrepreneurs from managers?", Journal of Business Venturing, Vol. 13 No. 4, pp. 295-316.

Churchill, G.A. Jr (1979), “A paradigm for developing better measures of marketing constructs”, Journal of Marketing Research, Vol. 16 No. 1, pp. 64-73.

Confucius Institute (2016), "Entering the era of entrepreneurship and innovation in China", available at: $\mathrm{http}: / /$ confuciusmag.com/entrepreneurship-innovation (accessed July 16, 2017).

Cox, L.W., Mueller, S.L. and Moss, S.E. (2002), "The impact of entrepreneurship education on entrepreneurial self-efficacy", International Journal of Entrepreneurship Education, Vol. 1 No. 2, pp. 229-245.

Davis, K. (2013), “The rise of online entrepreneurs: ecommerce by the numbers (Infographic)", available at: www.entrepreneur.com/article/227241 (accessed June 20, 2017).

DeLone, W.H. and McLean, E.R. (2003), "The DeLone and McLean model of information systems success: a ten-year update", Journal of Management Information Systems, Vol. 19 No. 4, pp. 9-30.

DeLone, W.H. and McLean, E.R. (2004), "Measuring e-commerce success: applying the DeLone \& McLean information systems success model”, International Journal of Electronic Commerce, Vol. 9 No. 1, pp. 31-47.

De Noble, A.F., Jung, D. and Ehrlich, S.B. (1999), "Entrepreneurial self-efficacy: the development and its relationship to entrepreneurial action", Frontier for Entrepreneurship Research, available at: https:/fusionmx.babson.edu/entrep/fer/papers99///I_C/IC.html (accessed August 15, 2017).

Devsaran (2017), "The internet entrepreneur: leveraging the World Wide Web for monetary gain", available at: www.devsaran.com/blog/internet-entrepreneur-leveraging-world-wide-webmonetary-gain (accessed December 22, 2018).

Duffy, B.E. and Pruchniewska, U. (2017), "Gender and self-enterprise in the social media age: a digital double bind”, Information, Communication \& Society, Vol. 20 No. 6, pp. 843-859.

Durndell, A. and Haag, Z. (2002), "Computer self-efficacy, computer anxiety, attitudes towards the internet and reported experience with the internet, by gender, in an East European sample", Computers in Human Behavior, Vol. 18 No. 5, pp. 521-535.

Eccles, J.S. (1994), "Understanding women's educational and occupational choices", Psychology of Women Quarterly, Vol. 18 No. 4, pp. 585-609.

Engard, B. (2016), “Tips for becoming a successful Internet entrepreneur”, available at: https://online. philau.edu/communications/successful-Internet-entrepreneur (accessed June 28, 2017).

Entrepreneur India (2018), “Top 3 entrepreneurial opportunities in digital marketing: the positive thing is that digital marketing services are not limited by their own skills and bandwidth", available at: www.entrepreneur.com/article/314639 (accessed January 31, 2019).

Epoch Times (2017), "With huge e-commerce market, you can be a master of online auction in universities", Epoch Times, November 24, available at: www.epochtimes.com/b5/17/11/23/ n9886161.htm (accessed January 20, 2019). 
Fang, Y.H. (2017), "Beyond the usefulness of branded applications: insights from consumer-brand engagement and self-construal perspectives”, Psychology \& Marketing, Vol. 34 No. 1, pp. 40-58.

Field, A.P. (2005), Discovering Statistics Using SPSS, 2nd ed., Sage, London.

Florin, J., Karri, R. and Rossiter, N. (2007), "Fostering entrepreneurial drive in business education: an attitudinal approach", Journal of Management Education, Vol. 31 No. 1, pp. 17-42.

Forbes, D.P. (2005), "The effects of strategic decision making on entrepreneurial self-efficacy", Entrepreneurship Theory and Practice, Vol. 29 No. 5, pp. 599-626.

Internet

entrepreneurial self-efficacy

scale

Fornell, C. and Larcker, D.F. (1981), "Evaluating structural equation models with unobservable variables and measurement error", Journal of Marketing Research, Vol. 18 No. 1, pp. 39-50.

Gist, M.E. and Mitchell, T.R. (1992), "Self-efficacy: a theoretical analysis of its determinants and malleability", Academy of Management Review, Vol. 17 No. 2, pp. 183-211.

Grant, E. (2018), “Online business vs offline”, available at: https://ecommerce-platforms.com/articles/ online-business-vs-offline (accessed February 1, 2019).

Guo, R., Cai, L. and Zhang, W. (2016), "Effectuation and causation in new internet venture growth: the mediating effect of resource bundling strategy", Internet Research, Vol. 26 No. 2, pp. 460-483.

Hair, J.F. Jr, Black, W.C., Babin, B.J. and Anderson, R.E. (2010), Multivariate Data Analysis: A Global Perspective, 7th ed., Prentice Hall, Upper Saddle River, NJ.

Hinkin, T.R. (1998), "A brief tutorial on the development of measures for use in survey questionnaires", Organizational Research Methods, Vol. 1 No. 1, pp. 104-121.

Hmieleski, K.M. and Baron, R.A. (2008), "When does entrepreneurial self-efficacy enhance versus reduce firm performance?”, Strategic Entrepreneurship Journal, Vol. 2 No. 1, pp. 57-72.

Kerr, S. and Jermier, J.M. (1978), "Substitutes for leadership: their meaning and measurement", Organizational Behavior and Human Performance, Vol. 22 No. 3, pp. 375-403.

Kickul, J., Gundry, L.K., Barbosa, S.D. and Whitcanack, L. (2009), "Intuition versus analysis? Testing differential models of cognitive style on entrepreneurial self-efficacy and the new venture creation process", Entrepreneurship Theory and Practice, Vol. 33 No. 2, pp. 439-453.

Kickul, J., Wilson, F., Marlino, D. and Barbosa, S.D. (2008), "Are misalignments of perceptions and self-efficacy causing gender gaps in entrepreneurial intentions among our nation's teens?”, Journal of Small Business and Enterprise Development, Vol. 15 No. 2, pp. 321-335.

Koçoğlu, İ., Akgun, A.E. and Keskin, H. (2017), "The role of business model development in the ex-post creation of online entrepreneurial opportunity", in Capatina, A. and Rancati, E. (Eds), Key Challenges and Opportunities in Web Entrepreneurship, IGI Global, Hershey, PA, pp. 1-32.

Krueger, N.F. and Brazeal, D.V. (1994), "Entrepreneurial potential and potential entrepreneurs", Entrepreneurship Theory and Practice, Vol. 18 No. 3, pp. 91-104.

Krueger, N.F., Reilly, M.D. and Carsrud, A.L. (2000), “Competing models of entrepreneurial intentions”, Journal of Business Venturing, Vol. 15 No. 5, pp. 411-432.

Kwan, I.S., Fong, J. and Wong, H.K. (2005), "An e-customer behavior model with online analytical mining for internet marketing planning”, Decision Support Systems, Vol. 41 No. 1, pp. 189-204.

McGee, J.E., Peterson, M., Mueller, S.L. and Sequeira, J.M. (2009), "Entrepreneurial self-efficacy: refining the measure", Entrepreneurship Theory and Practice, Vol. 33 No. 4, pp. 965-988.

Markman, G.D., Balkin, D.B. and Baron, R.A. (2002), "Inventors and new venture formation: the effects of general self-efficacy and regretful thinking", Entrepreneurship Theory and Practice, Vol. 27 No. 2, pp. 149-165.

Martin, B.C., McNally, J.J. and Kay, M.J. (2013), "Examining the formation of human capital in entrepreneurship: a meta-analysis of entrepreneurship education outcomes", Journal of Business Venturing, Vol. 28 No. 2, pp. 211-224.

Millman, C., Li, Z., Matlay, H. and Wong, W.C. (2010), "Entrepreneurship education and students' Internet entrepreneurship intentions: evidence from Chinese HEIs", Journal of Small Business and Enterprise Development, Vol. 17 No. 4, pp. 569-590. 
INTR 30,2

Mueller, S.L. and Goić, S. (2003), "East-West differences in entrepreneurial self-efficacy: implications for entrepreneurship education in transition economies", International Journal for Entrepreneurship Education, Vol. 1 No. 4, pp. 613-632.

Naktiyok, A., Karabey, C.N. and Gulluce, A.C. (2010), "Entrepreneurial self-efficacy and entrepreneurial intention: the Turkish case", International Entrepreneurship and Management Journal, Vol. 6 No. 4, pp. 419-435.

Newman, A., Obschonka, M., Schwarz, S., Cohen, M. and Nielsen, I. (2019), "Entrepreneurial self-efficacy: a systematic review of the literature on its theoretical foundations, measurement, antecedents, and outcomes, and an agenda for future research", Journal of Vocational Behavior, Vol. 110, Special Issue, pp. 403-419.

Nunnally, J.C. (1978), Psychometric Theory, 2nd ed., McGraw-Hill, New York, NY.

Peterson, R.A. (2000), Constructing Effective Questionnaires, Sage, Thousand Oaks, CA.

Ryan, D. (2017), Understanding Digital Marketing, 4th ed., Kogan Page, London.

Salehi, M., Mirzaei, H., Aghaei, M. and Abyari, M. (2012), "Dissimilarity of E-marketing vs traditional marketing", International Journal of Academic Research in Business and Social Sciences, Vol. 2 No. 1, pp. 814-825.

Scherer, R.F., Adams, J.S., Carley, S. and Wiebe, F.A. (1989), "Role model performance effects on development of entrepreneurial career preference", Entrepreneurship Theory \& Practice, Vol. 13 No. 3, pp. 53-71.

Schmitt, A., Rosing, K., Zhang, S.X. and Leatherbee, M. (2018), "A dynamic model of entrepreneurial uncertainty and business opportunity identification: exploration as a mediator and entrepreneurial self-efficacy as a moderator", Entrepreneurship Theory and Practice, Vol. 42 No. 6, pp. 835-859.

Sebora, T.C., Lee, S.M. and Sukasame, N. (2009), "Critical success factors for e-commerce entrepreneurship: an empirical study of Thailand", Small Business Economics, Vol. 32 No. 3, pp. 303-316.

Smale, T. (2016), “5 must-have skills for running an online business", available at: www.entrepreneur. com/article/277462 (accessed January 12, 2019).

Strauss, J. and Frost, R. (2014), E-Marketing, 7th ed., Pearson, Upper Saddle River, NJ.

Stumpf, S.A., Brief, A.P. and Hartman, K. (1987), "Self-efficacy expectations and coping with career-related events", Journal of Vocational Behavior, Vol. 31 No. 1, pp. 91-108.

Su, Y.S., Chiang, W.L., Lee, C.T.J. and Chang, H.C. (2016), "The effect of flow experience on player loyalty in mobile game application", Computers in Human Behavior, Vol. 63, pp. 240-248.

Top, S., Çolakoğlu, N. and Dilek, S. (2012), "Evaluating entrepreneurship intentions of vocational high school pupils based on self-efficacy concept”, Procedia-Social and Behavioral Sciences, Vol. 58, pp. 934-943.

Torkzadeh, G. and Koufteros, X. (1994), "Factorial validity of a computer self-efficacy scale and the impact of computer training", Educational and Psychological Measurement, Vol. 54 No. 3, pp. 813-821.

Torkzadeh, G., Chang, J.C.J. and Demirhan, D. (2006), “A contingency model of computer and Internet self-efficacy”, Information \& Management, Vol. 43 No. 4, pp. 541-550.

Tseng, T.H. and Lee, C.T. (2018), "Facilitation of consumer loyalty toward branded applications: the dual-route perspective", Telematics and Informatics, Vol. 35 No. 5, pp. 1297-1309.

US Department of Commerce (2016), "U.S. department of commerce invests $\$ 15$ million in entrepreneurs across the nation to move ideas to market, promote American innovation", available at: www.commerce.gov/news/press-releases/2016/11/us-department-commerceinvests-15-million-entrepreneurs-across-nation (accessed July 5, 2017).

Varadarajan, R. and Yadav, M.S. (2009), "Marketing strategy in an internet-enabled environment: a retrospective on the first ten years of JIM and a prospective on the next ten years", Journal of Interactive Marketing, Vol. 23 No. 1, pp. 11-22. 
WAHM (2009), "Key differences between an offline and online small business", available at: www. wahm.com/articles/key-differences-between-an-offline-and-online-small-business.html (accessed February 1, 2019).

Wang, Y.S. (2003), "Assessment of learner satisfaction with asynchronous electronic learning systems", Information \& Management, Vol. 41 No. 1, pp. 75-86.

Wang, Y.S. (2008), "Assessing e-commerce systems success: a respecification and validation of the DeLone and McLean model of IS success", Information Systems Journal, Vol. 18 No. 5, pp. 529-557.

Wang, Y.S., Lin, S.J., Yeh, C.H., Li, C.R. and Li, H.T. (2016), "What drives students' cyber entrepreneurial intention: the moderating role of disciplinary difference", Thinking Skills and Creativity, Vol. 22, pp. 22-35.

Wang, Y.S., Tseng, T.H., Wang, W.T., Shih, Y.W. and Chan, P.Y. (2019), "Developing and validating a mobile catering app success model", International Journal of Hospitality Management, Vol. 77, pp. 19-30.

Wei, P.S. and Lu, H.P. (2013), “An examination of the celebrity endorsements and online customer reviews influence female consumers' shopping behavior", Computers in Human Behavior, Vol. 29 No. 1, pp. 193-201.

Wilson, F., Kickul, J. and Marlino, D. (2007), "Gender, entrepreneurial self-efficacy, and entrepreneurial career intentions: implications for entrepreneurship education”, Entrepreneurship Theory and Practice, Vol. 31 No. 3, pp. 387-406.

Wilson, M. (2013), “7 Skills for successful internet entrepreneurship”, available at: https://under30ceo. com/7-skills-for-successful-internet-entrepreneurship (accessed November 11, 2018).

Wing-Fai, L. (2016), "The strengths of close ties: Taiwanese online entrepreneurship, gender and intersectionality", Information, Communication \& Society, Vol. 19 No. 8, pp. 1046-1060.

Wrobel, M. (2018), "Do you have what it takes to become an Internet entrepreneur? The key competencies of successful founders", in Richter, N., Jackson, P. and Schildhauer, T. (Eds), Entrepreneurial Innovation and Leadership, Palgrave Pivot, Cham, pp. 51-63.

Wymbs, C. (2011), "Digital marketing: the time for a new 'academic major' has arrived", Journal of Marketing Education, Vol. 33 No. 1, pp. 93-106.

$\mathrm{Xu}, \mathrm{P} ., \mathrm{Chen}, \mathrm{L}$. and Santhanam, R. (2015), "Will video be the next generation of e-commerce product reviews? Presentation format and the role of product type", Decision Support Systems, Vol. 73, pp. 85-96.

Yu, X., Roy, S.K., Quazi, A., Nguyen, B. and Han, Y. (2017), "Internet entrepreneurship and 'the sharing of information' in an Internet-of-Things context: the role of interactivity, stickiness, e-satisfaction and word-of-mouth in online SMEs' websites", Internet Research, Vol. 27 No. 1, pp. 74-96.

Zhao, H., Seibert, S.E. and Hills, G.E. (2005), "The mediating role of self-efficacy in the development of entrepreneurial intentions", Journal of Applied Psychology, Vol. 90 No. 6, pp. 1265-1272.

\section{Corresponding author}

Timmy H. Tseng can be contacted at: littlebeeballball@hotmail.com

For instructions on how to order reprints of this article, please visit our website:

www.emeraldgrouppublishing.com/licensing/reprints.htm

Or contact us for further details: permissions@emeraldinsight.com 